\title{
Simulating the formation of carbonaceous aerosol in a European Megacity (Paris) during the MEGAPOLI summer and winter campaigns
}

\author{
Christos Fountoukis ${ }^{1}$, Athanasios G. Megaritis ${ }^{2}$, Ksakousti Skyllakou ${ }^{2}$, Panagiotis E. Charalampidis ${ }^{1,3}$, \\ Hugo A. C. Denier van der Gon ${ }^{4}$, Monica Crippa ${ }^{5,6}$, André S. H. Prévôt ${ }^{6}$, Friederike Fachinger ${ }^{7}$, \\ Alfred Wiedensohler ${ }^{8}$, Christodoulos Pilinis ${ }^{3}$, and Spyros N. Pandis ${ }^{1,2,9}$ \\ ${ }^{1}$ Institute of Chemical Engineering Sciences, Foundation for Research and Technology Hellas (FORTH), \\ 26504 Patras, Greece \\ ${ }^{2}$ Department of Chemical Engineering, University of Patras, 26500 Patras, Greece \\ ${ }^{3}$ Department of Environment, University of the Aegean, 81100 Mytilene, Greece \\ ${ }^{4}$ TNO Climate, Air and Sustainability, P.O. Box 80015, 3508 TA Utrecht, the Netherlands \\ ${ }^{5}$ European Commission, Joint Research Centre (JRC), Institute for Environment and Sustainability (IES), Air and Climate \\ Unit, Via Fermi, 2749, 21027 Ispra, Italy \\ ${ }^{6}$ Laboratory of Atmospheric Chemistry, Paul Scherrer Institute, PSI Villigen, Switzerland \\ ${ }^{7}$ Max Planck Institute for Chemistry, Particle Chemistry Department, Mainz, Germany \\ ${ }^{8}$ Leibniz Institute for Tropospheric Research, Leipzig, Germany \\ ${ }^{9}$ Department of Chemical Engineering, Carnegie Mellon University, Pittsburgh, Pennsylvania, USA
}

Correspondence to: Spyros N. Pandis (spyros@chemeng.upatras.gr)

Received: 12 June 2015 - Published in Atmos. Chem. Phys. Discuss.: 17 September 2015

Revised: 13 January 2016 - Accepted: 4 March 2016 - Published: 21 March 2016

\begin{abstract}
We use a three-dimensional regional chemical transport model (PMCAMx) with high grid resolution and high-resolution emissions $\left(4 \times 4 \mathrm{~km}^{2}\right)$ over the Paris greater area to simulate the formation of carbonaceous aerosol during a summer (July 2009) and a winter (January/February 2010) period as part of the MEGAPOLI (megacities: emissions, urban, regional, and global atmospheric pollution and climate effects, and Integrated tools for assessment and mitigation) campaigns. Model predictions of carbonaceous aerosol are compared against Aerodyne aerosol mass spectrometer and black carbon (BC) high time resolution measurements from three ground sites. PMCAMx predicts $\mathrm{BC}$ concentrations reasonably well reproducing the majority (70\%) of the hourly data within a factor of two during both periods. The agreement for the summertime secondary organic aerosol $(\mathrm{OA})$ concentrations is also encouraging (mean bias $=0.1 \mu \mathrm{g} \mathrm{m}^{-3}$ ) during a photochemically intense period. The model tends to underpredict the summertime primary OA concentrations in the Paris greater area (by approxi-
\end{abstract}

mately $0.8 \mu \mathrm{g} \mathrm{m}^{-3}$ ) mainly due to missing primary OA emissions from cooking activities. The total cooking emissions are estimated to be approximately $80 \mathrm{mg} \mathrm{d}^{-1}$ per capita and have a distinct diurnal profile in which $50 \%$ of the daily cooking OA is emitted during lunch time (12:00-14:00 LT) and $20 \%$ during dinner time (20:00-22:00 LT). Results also show a large underestimation of secondary OA in the Paris greater area during wintertime (mean bias $=-2.3 \mu \mathrm{g} \mathrm{m}^{-3}$ ) pointing towards a secondary $\mathrm{OA}$ formation process during low photochemical activity periods that is not simulated in the model.

\section{Introduction}

Megacities (cities with more than 10 million inhabitants) are major sources of gas and particulate pollutants affecting public health, regional ecosystems, and climate. Rapid urbanization requires efficient emission control strategies and cost- 
effective air quality management. One of the main challenges in the design of abatement strategies for large urban agglomerations is the quantification of the contributions of local and long-range pollutant transport as well as the identification of the emission areas affecting the receptor. Ambient fine particulate matter $\left(\mathrm{PM}_{2.5}\right)$ is one of the main targets of such pollution reduction strategies. Organic aerosol makes up a large part of $\mathrm{PM}_{2.5}$ but despite its importance, it remains the least understood component of the atmospheric aerosol system. Understanding the formation and sources of organic aerosol in megacities is a critical step towards developing efficient mitigation strategies.

Intensive field measurement campaigns have been performed to characterize the chemical composition of particulate and gaseous pollutants in megacities such as New York (Sun et al., 2011), the Los Angeles basin (Hersey et al., 2011), Mexico City (Molina et al., 2010), London (Allan et al., 2010), Tokyo (Xing et al., 2011), and Beijing (Sun et al., 2010). In Europe comprehensive atmospheric measurements were recently conducted in the Paris metropolitan area as part of the MEGAPOLI project (Crippa et al., 2013a, b, c; Freutel et al., 2013; Freney et al., 2014). Freutel et al. (2013) analyzed aerosol mass spectrometer (AMS) measurements from three stationary sites in the Paris area during July 2009. They found that the origin of air masses had a large influence on secondary (oxygenated) organic aerosol (OOA) concentrations with elevated values (up to $7 \mu \mathrm{g} \mathrm{m}^{-3}$ ) observed during periods when the site was affected by transport from continental Europe and lower concentrations $\left(1-3 \mu \mathrm{g} \mathrm{m}^{-3}\right)$ when air masses were originating from the Atlantic. Crippa et al. (2013a) used positive matrix factorization (PMF) to perform organic source apportionment during winter 2010 in Paris. They identified three dominant primary sources (traffic: $11-15 \%$ of OA, biomass burning: $13-15 \%$ and cooking up to $35 \%$ during meal hours). Oxygenated OA was found to contribute more than $50 \%$ to the total OA and included a highly oxidized factor and a less oxidized factor related to aged wood burning emissions. Crippa et al. (2013b) focused on secondary OA (SOA) during both winter and summer in Paris and showed that OOA (local semi-volatile OOA (SV-OOA) and regional low-volatility OOA (LV-OOA)) was significant during both seasons (24$50 \%$ of total OA), while contributions from photochemistrydriven OOA (daytime SV-OOA) (9\% of total OA) and aged marine OA ( $13 \%$ of total $\mathrm{OA})$ were also observed during summertime. A semivolatile nighttime OOA factor correlating with nitrate was also identified representing $2 \%$ of total OA during summer and $18 \%$ in winter. Freney et al. (2014) analyzed airborne AMS measurements during summer and found that OA increased with photochemical aging demonstrating that it is necessary to take into account a continentalscale geographical area (compared to a local/city-scale area) when assessing the formation of SOA from urban emissions.

Organic aerosol has hundreds of sources, both anthropogenic and natural, in both the particulate and gas phases, while it can undergo complex atmospheric chemical and physical processing (Hallquist et al., 2009). The description of all these emissions and processes in chemical transport models (CTMs) is not a trivial task. Earlier modeling efforts for the megacity of Paris (Sciare et al., 2010) have assumed that primary OA (POA) is non-volatile and used a single-step oxidation SOA scheme thus underestimating SOA concentrations by a factor of three. Even larger errors were encountered when aged air masses with high SOA levels arrived at the observation site. More recently, models taking into account the semivolatile nature of POA (Robinson et al., 2007) have been applied over Paris. Couvidat et al. (2013) applied the Polyphemus model, which incorporates a two-surrogate-species (hydrophilic/hydrophobic) SOA formation scheme taking into account POA volatility and chemical aging, during the MEGAPOLI July 2009 campaign. The model estimated a 30-38\% local contribution to $\mathrm{OA}$ at the city center and overpredicted morning OC concentrations. Zhang et al. (2013) implemented the volatility basis set (VBS) approach into the chemistry transport model CHIMERE and applied it to the greater Paris region for the summer MEGAPOLI campaign. Simulation of organic aerosol with the VBS approach showed the best correlation with measurements compared to other modeling approaches. They also showed that advection of SOA from outside Paris was mostly responsible for the highest OA concentration levels. Fountoukis et al. (2013) examined the role of horizontal grid resolution on the performance of the regional 3-D CTM PMCAMx over the Paris greater area during both summer and winter and concluded that the major reasons for the discrepancies between the model predictions and observations in both seasons are not due to the grid scale used, but to other problems (e.g., emissions and/or process description). Skyllakou et al. (2014), using the particulate matter source apportionment technology (PSAT) together with PMCAMx, showed that approximately $50 \%$ of the predicted fresh POA originated from local sources and another $45 \%$ from areas $100-500 \mathrm{~km}$ away from the receptor region during summer in Paris. Furthermore they found that more than $45 \%$ of OOA was due to the oxidation of volatile organic compounds (VOCs) that were emitted $100-500 \mathrm{~km}$ away from the center of Paris.

Although several uncertainties still exist in OA modeling (e.g. related to POA volatility, SOA yields, the aging parameterization), evaluation and improvement of emission inventories from megacities as well as from surrounding areas is of fundamental importance. Furthermore, the description of the subsequent aging of the emitted organic material and the formation of OOA is critical in OA modeling. In this work we use the 3-D regional CTM PMCAMx with fine grid resolution to evaluate the $\mathrm{OA}$ and $\mathrm{BC}$ emission inventory in the megacity of Paris. We use an extensive set of factor analysis AMS data which allows a more in-depth evaluation of the formation and evolution of OA. We identify and quantify missing sources of OA during both seasons, explore possible 
emission and meteorological errors affecting the predicted $\mathrm{BC}$ concentrations and discuss missing or inadequate processes forming $\mathrm{OA}$ in the model.

\section{Model description}

PMCAMx (Tsimpidi et al., 2010; Fountoukis et al., 2011, 2014b) describes the processes of horizontal and vertical transport, gas- and aqueous-phase chemistry, aerosol dynamics and chemistry, and wet and dry deposition. It is based on the framework of the CAMx air quality model (ENVIRON, 2003). An extended SAPRC99 mechanism (ENVIRON, 2003) is used in the gas-phase chemistry module. The OA treatment in PMCAMx is based on the volatility basis set (VBS) approach (Donahue et al., 2006, 2009) for both primary and secondary organic species. Primary OA is assumed to be semivolatile with nine surrogate POA species used, corresponding to nine effective saturation concentrations ranging from $10^{-2}$ to $10^{6} \mathrm{\mu g} \mathrm{m}^{-3}$ (at $298 \mathrm{~K}$ ) in logarithmically spaced bins (Shrivastava et al., 2008). POA is simulated in the model as fresh (unoxidized) POA and oxidized POA from (i) intermediate volatility organic compounds (IVOCs) and (ii) semi-volatile organic compounds (SVOCs) (SOA-iv and SOA-sv, respectively). The IVOCs emissions are assumed to be proportional (by a factor of 1.5) to the emitted primary OA mass (Tsimpidi et al., 2010; Shrivastava et al., 2008). The SOA volatility basis-set approach (Lane et al., 2008) of the model includes four SOA species for each VOC with four volatility bins $\left(1,10,100,1000 \mathrm{\mu g} \mathrm{m}^{-3}\right)$. Chemical aging is modeled through gas-phase oxidation of OA vapors using a gas-phase $\mathrm{OH}$ reaction with a rate constant of $1 \times 10^{-11} \mathrm{~cm}^{3} \mathrm{molec}^{-1} \mathrm{~s}^{-1}$ for SOA from anthropogenic VOCs (aSOA-v) and $4 \times 10^{-11} \mathrm{~cm}^{3} \mathrm{molec}^{-1} \mathrm{~s}^{-1}$ for SOAsv and SOA-iv (Atkinson and Arey, 2003). Each reaction is assumed to decrease the volatility of the vapor material by one order of magnitude. More details about this version of the model can be found in Fountoukis et al. (2011, 2014b).

The parameterization of the biogenic SOA chemical aging in the VBS scheme in this work differs from that used by Zhang et al. (2013) in CHIMERE. In CHIMERE the biogenic SOA ages the same way as the anthropogenic SOA, while in our work these later generation reactions are assumed to lead to a zero net increase of the corresponding SOA because of a balance between the functionalization and fragmentation processes.

\section{Model application}

We simulate two periods (1-30 July 2009 and 10 January to 9 February 2010) during which intensive measurement campaigns were performed as part of MEGAPOLI. PMCAMx is used with a two-way nested grid structure which allows the model to run with coarse grid spacing over the regional domain of Europe, while within the same simulation, apply- ing a fine grid nest over the Paris greater area (Fig. 1). The necessary meteorological inputs to the model were generated from the WRF (Weather Research and Forecasting) model (Skamarock et al., 2008) and include horizontal wind components, vertical diffusivity, temperature, pressure, water vapor, clouds and rainfall. WRF was driven by static geographical data and dynamic meteorological data (near real-time and historical data generated by the Global Forecast System $\left.\left(1 \times 1^{\circ}\right)\right)$. Twenty-seven pressure layers up to 0.1 bars were used in the vertical dimension. Each layer of PMCAMx is aligned with the layers used in WRF. PMCAMx was set to perform simulations on a polar stereographic map projection with $36 \times 36 \mathrm{~km}^{2}$ grid spacing over the European domain and a $4 \times 4 \mathrm{~km}^{2}$ resolution over Paris. The European modeling domain covers a $5400 \times 5832 \mathrm{~km}^{2}$ region while the Paris subdomain covers a total area of $216 \times 180 \mathrm{~km}^{2}$ with the Metropolitan area of Paris located centrally in the subdomain. Fourteen vertical layers are used extending up to $6 \mathrm{~km}$ in height with a surface layer depth of $55 \mathrm{~m}$. The dimensions of the modeling domain are the same for both the summer and winter simulations. The model interpolates the meteorological input from the parent to the nested grid while high-resolution emissions are used in the Paris subdomain. Concentrations of species at the boundaries of the domain are based on measured average background concentrations in sites close to the boundaries of the domain (e.g. Zhang et al., 2007; Seinfeld and Pandis, 2006). We have used the same boundary conditions as in Fountoukis et al. (2011).

Inventories of both biogenic and anthropogenic emissions were developed and consist of hourly gridded emissions of gases as well as primary particulate matter. A description of the European emission data can be found in Pouliot et al. (2012). These emissions were modified by nesting high-resolution emissions with emission inventories for four megacities in the European coarser grid of $36 \times 36 \mathrm{~km}^{2}$. More specifically, the base case emission data originate from the Netherlands Organization for Applied Scientific Research (TNO) and were compiled as part of the MEGAPOLI project. They were spatially distributed at a resolution of $1 / 8^{\circ} \times 1 / 16^{\circ}$ (longitude $\times$ latitude). Furthermore, based on the TNO inventory, bottom-up emission data were used for four European megacities (Paris, London, Rhine-Ruhr and Po Valley). A description of the procedure for the nesting, comparison and origin of the different emission inventories is given in Kuenen et al. (2010) and Denier van der Gon et al. (2011).

The Paris emissions that form the core of the highresolution inventory for the domain used in this study originate from local authorities responsible for city emissions inventories and air quality (Airparif, 2010). A summary of total mass emission rates for the Paris greater area is given in Table 1. The largest source of primary OA in the wintertime emission inventory in Paris is residential (wood and fossil fuel) combustion, contributing $80 \%$ to the total anthropogenic OA emissions while during summer the traffic- 
Table 1. Emission mass totals (in tons/month) for the Paris greater area as shown in Fig. 1.

\begin{tabular}{|c|c|c|c|c|c|c|c|c|c|c|c|c|c|c|}
\hline \multirow[t]{2}{*}{ Species } & \multirow[t]{2}{*}{$\mathrm{CO}$} & \multirow[t]{2}{*}{ NO } & \multirow[t]{2}{*}{$\mathrm{SO}_{2}$} & \multirow[t]{2}{*}{$\mathrm{NH}_{3}$} & \multicolumn{3}{|c|}{ VOCs } & \multirow[t]{2}{*}{ Nitrate } & \multirow[t]{2}{*}{ Sulfate } & \multirow[t]{2}{*}{ Ammonium } & \multirow[t]{2}{*}{$\mathrm{BC}$} & \multirow[t]{2}{*}{ OC } & \multirow[t]{2}{*}{ Sodium } & \multirow[t]{2}{*}{ Chloride } \\
\hline & & & & & Isoprene & $\mathrm{MT}^{1}$ & Other $^{2}$ & & & & & & & \\
\hline & \multicolumn{14}{|c|}{ Summer 2009} \\
\hline Anthropogenic & 27307 & 10562 & 556 & 1877 & - & - & 12042 & - & 44 & - & 455 & 1058 & 12 & - \\
\hline Natural (land) & 2247 & 204 & - & - & 2861 & 1435 & 2390 & - & - & - & - & - & - & - \\
\hline \multirow[t]{2}{*}{ Natural (fires) } & 340 & 10 & 2 & 5 & - & - & 5 & 3 & 7 & 1 & 7 & 23 & - & - \\
\hline & \multicolumn{14}{|c|}{ Winter 2010} \\
\hline Anthropogenic & 54041 & 15440 & 5713 & 1999 & - & - & 17089 & - & 158 & - & 726 & 1892 & 32 & - \\
\hline Natural (land) & 314 & 30 & - & - & 26 & 211 & 301 & - & - & - & - & - & - & - \\
\hline
\end{tabular}

${ }^{1}$ MT: Monoterpene emissions. ${ }^{2}$ Other: Other VOCs excluding methane and methanol.

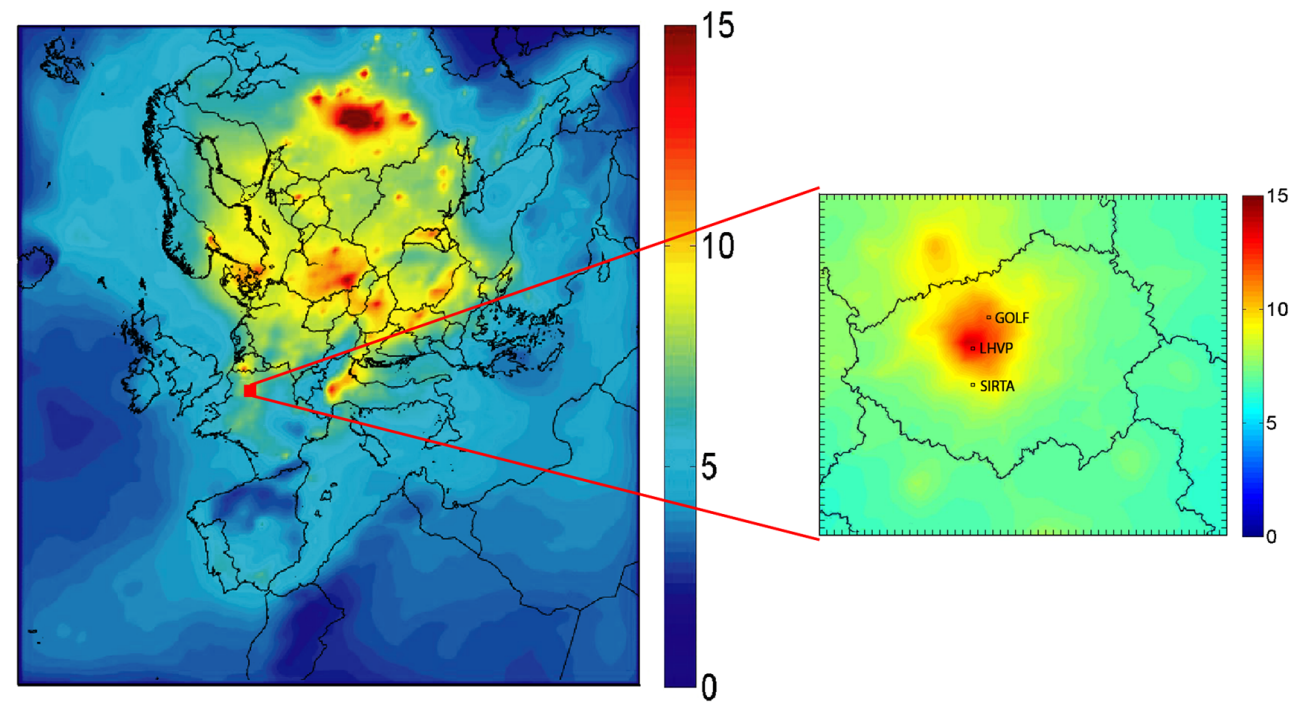

Figure 1. Modeling domain of PMCAMx for Europe. Also shown are the three measurement stations in the nested $4 \times 4 \mathrm{~km}^{2}$ subdomain of Paris. Color coding shows the predicted average ground concentrations (in $\mu \mathrm{g} \mathrm{m}^{-3}$ ) of $\mathrm{PM}_{1}$ during winter 2010.

related sector dominates with $35 \%$ contribution (Supplement Table S1). During winter the traffic sector contributes approximately $40 \%$ to the total $\mathrm{BC}$ emissions in the Paris subdomain. This is more than a factor of two higher than the European average contribution and is due to the dense population in this area. The residential combustion sector contributes approximately $45 \%$ to the wintertime $\mathrm{BC}$ emissions in the Paris area which is about the same as the European average indicating low emissions per inhabitant in the Paris greater area for this specific source sector.

The chemical speciation of the volatile organic compounds is based on the speciation approach proposed by Visschedijk et al. (2007). Biogenic emissions were estimated using three distinct inventories. Plant canopy gridded emissions were estimated by utilizing the MEGAN (Model of Emissions of Gases and Aerosols from Nature) model (Guenther et al., 2006). MEGAN inputs are meteorological parameters estimated by the WRF model, the leaf area index and a set of emission factors for various chemical species at standard conditions. Since a large portion of the domain is covered by sea, marine aerosol emissions are also included. These are based on a marine aerosol model (O'Dowd et al., 2008) that estimates mass fluxes for both accumulation and coarse mode including an organic fine mode aerosol fraction. Inputs of the specific marine model are the wind speed components calculated by WRF and the chlorophyll $a$ concentrations acquired using the GES-DISC Interactive Online Visualization and Analysis Infrastructure (GIOVANNI) as part of the NASA's Goddard Earth Sciences (GES) Data and Information Services Center (DISC). Finally wildfire emissions are also included (Sofiev et al., 2009).

\section{Measurements}

Two intensive field campaigns were performed as part of the MEGAPOLI project (http://megapoli.dmi.dk/index.html) during summer (July 2009) and winter (January/February 2010) in the Paris area including AMS measurements of fine particulate matter from three ground sites (Beekmann 
et al., 2015). The Laboratoire d'Hygiène de la Ville de Paris (LHVP; Paris, 13th district; $48.827^{\circ} \mathrm{N}, 2.358^{\circ} \mathrm{E}$ ) monitoring station is in the center of the city and is representative of Paris urban background air pollution (Sciare et al., 2010; Favez et al., 2007). SIRTA (Site Instrumental de Recherche par Télédétection Atmosphérique) is located in Palaiseau $\left(48.714^{\circ} \mathrm{N}, 2.203^{\circ} \mathrm{E}\right), 20 \mathrm{~km}$ southwest of the city center and is characteristic of a suburban environment (Haeffelin et al., 2005). The GOLF (GOLF Poudrière) site $\left(48.934^{\circ} \mathrm{N}\right.$, $2.547^{\circ} \mathrm{E}$ ) is located approximately $20 \mathrm{~km}$ to the northeast of the city center and is also suburban influenced by local (medium) traffic. High-resolution time-of-flight aerosol mass spectrometers (HR-ToF-AMS) (DeCarlo et al., 2006) were used at both the SIRTA and LHVP sites, while a compact ToF-AMS (C-ToF-AMS) (Drewnick et al., 2005) was deployed at GOLF. AMS OA measurements were analyzed by factor analysis (Crippa et al., 2013b) using the multi-linear engine (ME-2) algorithm (Paatero, 1999; Canonaco et al., 2013), the PMF2 algorithm (Freutel et al., 2013) and the PET toolkit of Ulbrich et al. (2009) (Crippa et al., 2013a, c). The factor analysis data used in this work are taken from Crippa et al. (2013b) for LHVP, from Crippa et al. (2013c) for SIRTA and from Freutel et al. (2013) for the GOLF site during the summer period while during winter all the data are taken from Crippa et al. (2013a). Table 2 shows the various OA components identified by the PMF analysis in each site and season. During the winter campaign factor analysis identified two primary OA components (hydrocarbon-like organic aerosol (HOA) and biomass burning OA (BBOA)) in GOLF with the addition of cooking-related organic aerosol (COA) component in LHVP and SIRTA. Two secondary components (low-volatility OOA related to wood burning emissions and a highly oxidized OOA factor) were identified in LHVP and GOLF and one OOA component in SIRTA. During summertime two primary OA components (COA and HOA) were identified in LHVP and SIRTA and one component (HOA) at GOLF. Finally, one OOA component was identified in GOLF, while three (marine-related OA, (MOA), low-volatility oxygenated OA (LV-OOA) and semi-volatile oxygenated OA (SV-OOA)) were identified at SIRTA and LHVP. BC was measured using a multi-angle absorption photometer (MAAP) in LHVP and GOLF and an Aethalometer in SIRTA (Freutel et al., 2013). The measurement uncertainty for the Aethalometer and MAAP was 30 and $10 \%$, respectively (Freutel et al., 2013).

\section{Results and discussion}

\subsection{Model predictions over the Paris greater area}

Figure 2 shows the predicted average ground-level concentrations of fine fresh primary OA, secondary OA and $\mathrm{BC}$ in the greater Paris area during July 2009 and January/February 2010. Overall, carbonaceous aerosol is predicted to account
Table 2. OA components identified by the PMF analysis in each site during the MEGAPOLI summer and winter campaigns.

\begin{tabular}{lll}
\hline OA components & Summer & Winter \\
\hline LHVP & HOA, COA, LV-OOA, & HOA, BBOA, COA, \\
& SV-OOA, MOA & OOA1, OOA2 \\
SIRTA & HOA, COA, LV-OOA, & HOA, BBOA, COA, \\
& SV-OOA, MOA & OOA \\
GOLF & HOA, OOA & HOA, BBOA, OOA1, \\
& & OOA2 \\
\hline
\end{tabular}

for $36 \%$ of total dry $\mathrm{PM}_{1}$ mass concentration at ground level averaged over the Paris greater area domain during summer, followed by nitrate $(20 \%)$, sulfate $(16 \%)$ and ammonium (12\%) with the remaining $16 \%$ comprised of crustal material, sea salt and metal oxides. During the winter period the model predicts a higher contribution of carbonaceous aerosol (41\%) and lower contributions for the secondary species: sulfate $(12 \%)$, nitrate $(12 \%)$ and ammonium $(11 \%)$. Primary $\mathrm{OA}$ and $\mathrm{BC}$ are predicted to have higher levels in the city center while their concentrations decrease in the Parisian suburbs. The use of high-resolution in both the emissions and grid simulation results in larger spatial concentration gradients compared to the resolution of $36 \times 36 \mathrm{~km}^{2}$ used by Fountoukis et al. (2013). During the winter period the model predicts much higher concentrations for both POA and BC compared to summer. The two largest sources of primary carbonaceous aerosol are the traffic-related sector and the residential (fuel and wood) combustion processes. The traffic source sector dominates in the contribution of the OA and $\mathrm{BC}$ emissions during summer while during wintertime the residential combustion is the largest contributor.

Secondary OA concentrations show a regional character in their geographical distribution during both seasons with higher concentrations predicted during summer due to stronger photochemical activity. A west to east gradient is predicted during summer following the evolution of photochemistry and the increased atmospheric processing time. OOA is predicted to account for approximately $90 \%$ of $\mathrm{PM}_{1}$ $\mathrm{OA}$ at ground level over the Paris greater area (domainaverage) during summer and $50 \%$ during winter.

\subsection{Primary organic aerosol levels and sources}

The prediction skill metrics of PMCAMx against factoranalysis AMS data for total POA concentrations from all three stations in the Paris greater area are summarized in Table 3. Figure 3 shows an overall comparison of modeled versus observed values for both seasons. Primary OA in the model is the OA that is emitted in the particulate phase and has not undergone any chemical processing. The AMS total POA component in this comparison is the sum of HOA and COA during summer with the addition of BBOA during wintertime. During the summer period the model under- 

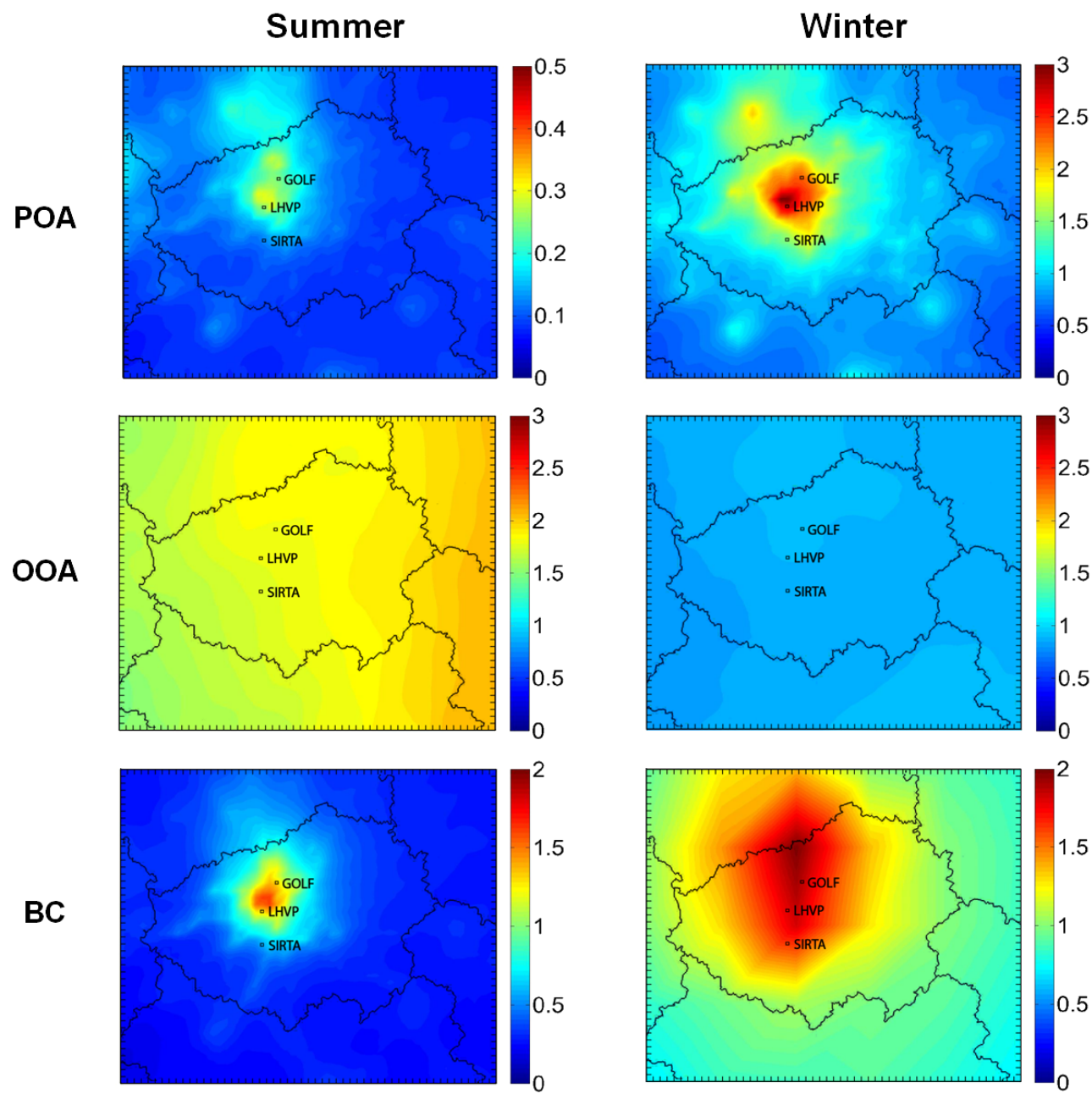

Figure 2. Predicted average ground concentrations (in $\mu \mathrm{g} \mathrm{m}^{-3}$ ) of fine fresh total POA, BC and OOA in the greater area of Paris during summer 2009 and winter 2010. Different scales are used.

predicts total POA concentrations at all sites by, on average, $0.8 \mu \mathrm{g} \mathrm{m}^{-3}$. Overall, only $15 \%$ of the hourly data from all sites (1700 data points in total) are predicted within a factor of two. At LHVP the agreement is slightly better but still poor, with $30 \%$ of the data predicted within a factor of two and a fractional error of 0.9 . The day-to-day variability of modeled and observed concentrations in Paris city center is provided in the Supplement (Fig. S1). The dailyaveraged total POA concentration is systematically underpredicted throughout most of the simulated days.

Factor analysis of the AMS data from downtown Paris showed that a major part (more than $70 \%$ ) of observed total POA concentrations originated from cooking activities $\left(0.5 \mu \mathrm{g} \mathrm{m}^{-3}\right.$ on average) while only another $0.2 \mu \mathrm{g} \mathrm{m}^{-3}$ was attributed to HOA from traffic-related sources (Crippa et al., 2013b). Emissions from cooking sources are not included in the baseline emission inventories that are used in this work (Denier van der Gon et al., 2011). Therefore any POA concentrations that the model predicts during the summer period
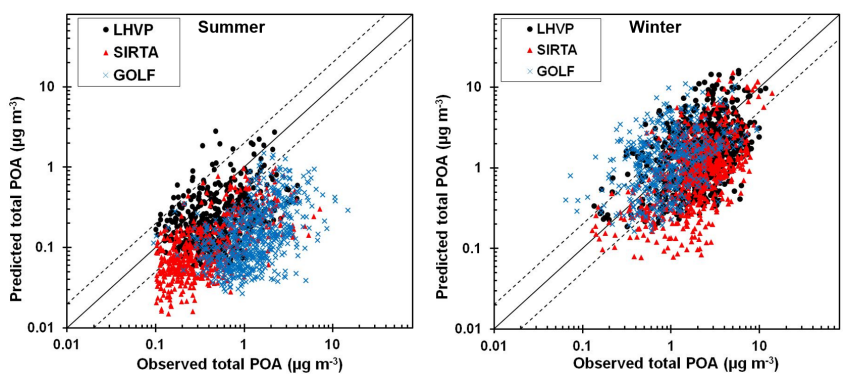

Figure 3. Comparison of predicted vs. observed $\mathrm{PM}_{1}$ total POA $\left(\mu \mathrm{g} \mathrm{m}^{-3}\right)$ from the three measurement stations during the MEGAPOLI summer and winter campaigns. Each point is an hourly average value. Also shown are the $1: 1,2: 1$ and $1: 2$ lines. Observed data represent AMS factor-analysis results. 
Table 3. Prediction skill metrics of PMCAMx against observed hourly data.

\begin{tabular}{|c|c|c|c|c|c|c|c|c|}
\hline \multirow[b]{2}{*}{ POA } & \multicolumn{4}{|c|}{ Summer } & \multicolumn{4}{|c|}{ Winter } \\
\hline & LHVP & SIRTA & GOLF & Average & LHVP & SIRTA & GOLF & Average \\
\hline Mean predicted $\left(\mu \mathrm{g} \mathrm{m}^{-3}\right)$ & 0.3 & 0.15 & 0.2 & 0.2 & 2.2 & 1.4 & 1.7 & 1.8 \\
\hline Mean observed $\left(\mu \mathrm{g} \mathrm{m}^{-3}\right)$ & 0.7 & 0.5 & 1.6 & 1 & 2.7 & 2.4 & 1.3 & 2.2 \\
\hline FERROR $^{1}$ & 0.9 & 1 & 1.5 & 1.1 & 0.7 & 0.8 & 0.65 & 0.7 \\
\hline FBIAS $^{2}$ & -0.7 & -0.9 & -1.5 & -1 & -0.3 & -0.6 & 0.2 & -0.3 \\
\hline $\operatorname{MAGE}^{3}\left(\mu \mathrm{g} \mathrm{m}^{-3}\right)$ & 0.4 & 0.4 & 1.4 & 0.8 & 1.7 & 1.5 & 1.1 & 1.4 \\
\hline $\mathrm{MB}^{4}\left(\mu \mathrm{g} \mathrm{m}^{-3}\right)$ & -0.3 & -0.4 & -1.4 & -0.8 & -0.5 & -1 & 0.4 & -0.4 \\
\hline \multicolumn{9}{|l|}{ OOA } \\
\hline Mean predicted $\left(\mu \mathrm{g} \mathrm{m}^{-3}\right)$ & 1.6 & 1.5 & 1.6 & 1.5 & 0.9 & 0.8 & 0.9 & 0.9 \\
\hline Mean observed $\left(\mu \mathrm{g} \mathrm{m}^{-3}\right)$ & 1.7 & 1.2 & 1.5 & 1.4 & 3.2 & 3.3 & 3 & 3.2 \\
\hline FERROR & 0.3 & 0.4 & 0.4 & 0.4 & 1.1 & 1.2 & 1.1 & 1.1 \\
\hline FBIAS & -0.05 & 0.2 & 0.02 & 0.05 & -1.1 & -1.1 & -1 & -1.1 \\
\hline $\operatorname{MAGE}\left(-\mathrm{g} \mathrm{m}^{-3}\right)$ & 0.4 & 0.5 & 0.5 & 0.5 & 2.3 & 2.5 & 2.1 & 2.3 \\
\hline $\operatorname{MB}\left(\mu \mathrm{g} \mathrm{m}^{-3}\right)$ & -0.1 & 0.3 & 0.07 & 0.1 & -2.3 & -2.5 & -2 & -2.3 \\
\hline \multicolumn{9}{|l|}{$\mathrm{BC}$} \\
\hline Mean predicted $\left(\mu \mathrm{g} \mathrm{m}^{-3}\right)$ & 1.6 & 0.6 & 1 & 1 & 1.9 & 1.8 & 2.3 & 2.1 \\
\hline Mean observed $\left(\mu \mathrm{g} \mathrm{m}^{-3}\right)$ & 1.3 & 0.65 & 1.1 & 1 & 1.4 & 0.9 & 2.1 & 1.8 \\
\hline FERROR & 0.5 & 0.6 & 0.4 & 0.5 & 0.5 & - & 0.5 & 0.5 \\
\hline FBIAS & 0.07 & -0.2 & -0.1 & -0.1 & 0.2 & - & 0.02 & 0.1 \\
\hline $\operatorname{MAGE}\left(\mu \mathrm{g} \mathrm{m}^{-3}\right)$ & 0.9 & 0.4 & 0.5 & 0.6 & 1 & - & 1.2 & 1.1 \\
\hline $\operatorname{MB}\left(\mu \mathrm{g} \mathrm{m}^{-3}\right)$ & 0.3 & -0.05 & -0.05 & 0.05 & 0.5 & - & 0.2 & 0.3 \\
\hline
\end{tabular}

${ }^{1}$ FERROR $=2 / n \sum_{i=1}^{n}\left|P_{i}-O_{i}\right| /\left(P_{i}+O_{i}\right)$, where $P_{i}$ represents the model predicted value for data point $i, O_{i}$ is the corresponding observed value and $n$ is the total number of data points. ${ }^{2}$ FBIAS $=2 / n \sum_{i=1}^{n}\left(P_{i}-O_{i}\right) /\left(P_{i}+O_{i}\right) .{ }^{3}$ MAGE $=1 / n \sum_{i=1}^{n}\left|P_{i}-O_{i}\right|$.

${ }^{4} \mathrm{MB}=1 / n \sum_{i=1}^{n}\left(P_{i}-O_{i}\right)$.

are mainly primary OA from traffic-related sources. This is further explored in Sect. 5.5.

During summer the model predicts low concentrations of vehicular POA in Paris, ranging on average between 0.2 and $0.3 \mu \mathrm{g} \mathrm{m}^{-3}$, in agreement with the observations (Fig. S2). There is little bias (FBIAS $=0.1$ ) and the mean error is $0.2 \mu \mathrm{g} \mathrm{m}^{-3}$ (Table S2). In SIRTA the predicted average diurnal profile compares well with the observations capturing the morning peak at $8 \mathrm{a} . \mathrm{m}$. The nocturnal bias in SIRTA (at 10 p.m.) is rather episodic with 2 days ( 4 and 11 July) exhibiting a large vehicular POA underprediction (by more than a factor of 5). Interestingly, observations show no clear morning peak at the city center. The model, however, predicts a distinct diurnal profile, overpredicting vehicular POA concentrations at LHVP during the morning rush hours. This overprediction of POA traffic concentrations could be related to emissions (e.g. emission rate errors, errors in the diurnal cycle of emissions, missing sources of total POA emissions, etc.), errors in the geographical distribution of emissions in the high-resolution domain (Fountoukis et al., 2013) or could also be affected by errors in the meteorology. The source apportionment method can also induce errors. As HOA concentrations are quite low, the HOA fraction estimated by the statistical model has a large uncertainty (30-50\%).
Meteorological parameters used as input to PMCAMx (temperature, relative humidity and wind velocity) were compared against measurements available at SIRTA (Fig. S3). In general, the WRF calculated meteorological fields are consistent with the measurements. Temperature is well reproduced with a mean bias of $-0.7^{\circ} \mathrm{C}$. There are a few days where WRF underpredicts the maximum daily observed temperature by $2-4^{\circ} \mathrm{C}$ which could theoretically result in an underestimation of POA evaporation and thus a small overprediction of POA. However, for the specific times of the day and certain days that the model shows somewhat large discrepancies compared to the observed temperature, no correlation with the POA or OOA bias is found. No systematic error is found in the wind velocity or relative humidity comparison (mean bias of $0.2 \mathrm{~m} \mathrm{~s}^{-1}$ and $-0.5 \%$, respectively).

During winter the agreement for total POA is better than in summer, with errors mostly due to scatter (mean er-

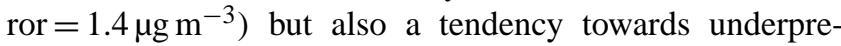
diction (mean bias $=-0.4 \mu \mathrm{g} \mathrm{m}^{-3}$ ) (Fig. S1). Factor analysis of the AMS data from the city center showed an average of $1 \mu \mathrm{g} \mathrm{m}^{-3}$ from cooking sources, $1 \mu \mathrm{g} \mathrm{m}{ }^{-3}$ from biomass burning and $0.7 \mu \mathrm{g} \mathrm{m}^{-3}$ from traffic (Crippa et al., 2013a). The model predicts an average of $2.2 \mu \mathrm{g} \mathrm{m}^{-3}$ for total POA which includes both vehicular POA and BBOA but no COA concentrations. Source apportionment results from 
Paris (Skyllakou et al., 2014) showed that approximately $70 \%$ of the modeled (PMCAMx) total POA concentration in Paris center is predicted to originate from biomass burning and $15 \%$ from traffic-related sources. This shows that the model underpredicts the concentrations of POA-traffic components during winter (Table S2) while the problem with the missing COA emissions still exists but is now a smaller fraction of the total POA. The comparison between the predicted BBOA concentrations from PSAT against the factor analysis BBOA (Fig. S4, Table S3) shows an overprediction in LHVP (mean bias $=0.3 \mu \mathrm{g} \mathrm{m}^{-3}$ ) and underprediction at SIRTA (mean bias $=-0.3 \mu \mathrm{g} \mathrm{m}^{-3}$ ) implying errors in the geographical distribution of residential wood burning emissions in the Paris greater area.

\subsection{Oxygenated organic aerosol}

Figure 4 shows the comparison of predicted OOA concentrations against the factor analysis AMS data for both seasons with the statistics of the comparison summarized in Table 3. The modeled OOA is defined as the sum of aSOA-v, bSOAv (SOA from biogenic VOCs), SOA-iv and SOA-sv. Contrary to POA, the comparison for OOA during the summer period is encouraging (Fig. S1). The model predicts an average of $1.5 \mu \mathrm{g} \mathrm{m}^{-3}$ of OOA at the three measurement sites without any significant concentration gradients between the city center (LHVP) and the suburban sites (Table 3) while a $1.4 \mu \mathrm{g} \mathrm{m}^{-3}$ average concentration was estimated by the factor analysis. A large fraction (54\%) of the predicted OOA concentration in LHVP is bSOA-v followed by SOA-sv and SOA-iv (33\%) and aSOA-v (13\%). Most of the OOA hourly measurements are reproduced within a factor of two $(80 \%$ in both LHVP and GOLF and $60 \%$ in SIRTA) highlighting the ability of the model to reproduce the major secondary OA transport and transformation processes during a photochemically intense period. This was also shown by Zhang et al. (2013) when using the VBS scheme as opposed to the single-step SOA formation mechanism in LHVP during summertime. However, in disagreement with this work, the VBS scheme assuming increasing biogenic SOA yields with chemical aging of Zhang et al. (2013) systematically overpredicts OOA concentrations in the city center (by up to a factor of two). PMCAMx reproduces the observed OOA concentrations in LHVP during summer with reasonable accuracy (1.7 compared to $1.6 \mu \mathrm{g} \mathrm{m}^{-3}$ predicted by the model with a -0.05 fractional bias).

During the winter period however, the model performance is very different than in July. PMCAMx largely underpredicts OOA concentrations at all three sites with an overall mean bias of $-2.3 \mu \mathrm{g} \mathrm{m}^{-3}$ (Table 3 ). It is noteworthy though that the OOA levels estimated by the PMF analysis during the winter period are more than a factor of two higher than that of the summer period. PMCAMx on the other hand predicts that OOA during winter is $30-50 \%$ lower than during summer. Only $25 \%$ of the hourly data (2230 in total) are pre-
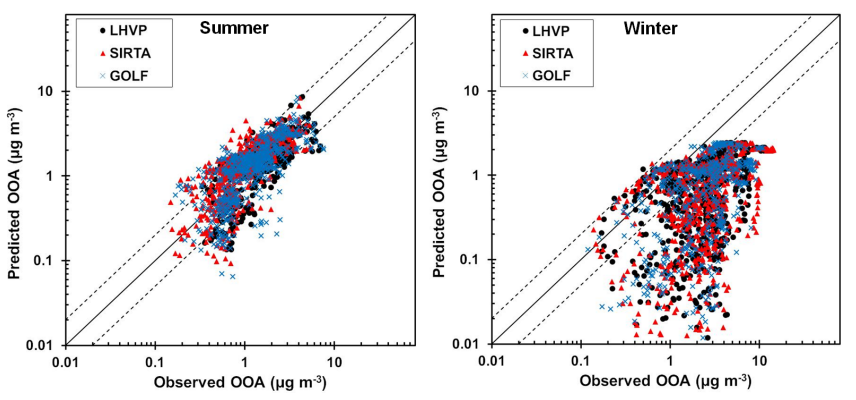

Figure 4. Comparison of predicted vs. observed $\mathrm{PM}_{1}$ OOA $\left(\mu \mathrm{g} \mathrm{m}^{-3}\right)$ from the three measurement stations during the MEGAPOLI summer and winter campaigns. Each point is an hourly average value. Also shown are the $1: 1,2: 1$ and $1: 2$ lines. Observed data represent AMS factor-analysis results.

dicted within a factor of two. The model predicts less than $1 \mu \mathrm{g} \mathrm{m}^{-3}$ of OOA in the Paris greater area while the factoranalysis estimated a concentration of more than $3 \mu \mathrm{g} \mathrm{m} \mathrm{m}^{-3}$. A time series analysis (Fig. S5) shows that the OOA underprediction is persistent throughout the whole simulation period (also seen in Fig. S1). However, there are certain days with large (a factor of 3-5) underestimation (24 and 27 January and 4 and 7 February) and a couple of other days during which the model performance is somewhat reasonable at least during certain hours of the day (29 January and 3 February). A back-trajectory analysis (Fig. S6) shows that during the days with the large underestimation, air masses originate from continental Europe, either within France or from the northeast (mostly Germany) while during the days with reasonable model performance the air masses were mostly clean coming from the Atlantic.

Possible reasons for this underprediction include errors in meteorology, emission rate errors of SOA precursors and missing or inadequate processes forming OOA in the model. However, no significant errors in the wintertime meteorological input were found from the evaluation of the meteorological parameters (Fig. S3). Furthermore, PMCAMx was found to perform reasonably well for other PM components (e.g. $\mathrm{BC}$ ) indicating that the meteorology is probably not the reason for the OOA underprediction. Simulations with PSAT together with PMCAMx showed that approximately $80 \%$ of the predicted OOA during winter in Paris originated from long-range transport from areas more than $500 \mathrm{~km}$ away from Paris. Compared to summer (45\%), the model simulates more contribution from long-range secondary OA sources during winter, because the timescale for its production is longer due to the slower photochemical activity (Skyllakou et al., 2014). Therefore any emission rate errors in OOA precursors, if true, should be present not only in the Paris greater area but also in the greater region of Europe. In fact recent studies (Bergström et al., 2012; Kostenidou et al., 2013; Fountoukis et al., 2014a; Denier van der Gon et al., 2015) have pointed towards large uncertainties in the biomass burn- 
ing emission estimates in many European areas. This could partly explain the wintertime underprediction of OOA in Paris. If BBOA emissions are significantly underestimated in European regions upwind of Paris, then the Parisian SOA-sv and SOA-iv concentrations formed in the model from BBOA would also be underestimated. From the factor analysis of Crippa et al. (2013b), an average of $1.3 \mu \mathrm{g} \mathrm{m}^{-3}$ was estimated for the oxygenated BBOA (OBBOA) concentration in Paris, significantly higher compared to the OBBOA predictions of PSAT $\left(0.2 \mu \mathrm{g} \mathrm{m}^{-3}\right)$. However, this can explain only part of the large underprediction of OOA $\left(-2.3 \mu \mathrm{g} \mathrm{m}^{-3}\right)$. Some recent studies have supported the transformation of BBOA to OOA without the presence of sunlight (Bougiatioti et al., 2014; Crippa et al., 2013a, b). A process-forming SOA (and involving high $\mathrm{NO}_{x}$ levels from polluted sites) that is not simulated in the model could explain the OOA underprediction in Paris. Furthermore, Fountoukis et al. (2014b) evaluated PMCAMx against OOA factor-analysis AMS measurements from several sites all over Europe (Fountoukis et al., 2014b) during a wintertime period (February/March 2009) and an autumn period (September/October 2008) and showed good agreement with observations from both periods (mean bias $=0.4$ and $-0.2 \mu \mathrm{g} \mathrm{m}^{-3}$ respectively). Contrary to the present study though, the measurement sites in Fountoukis et al. (2014b) study included only rural and remote areas, while the more than $3 \mu \mathrm{g} \mathrm{m}^{-3}$ of OOA observed in Paris is a lot higher than other wintertime measurements in Europe.

Other possible sources of uncertainty that are not explored here but have been investigated in past applications of PMCAMx include uncertainties in the aging scheme, the magnitude of IVOC emissions, aqueous secondary OA formation and others (Knote et al., 2014; Murphy et al., 2011, 2012; Tsimpidi et al., 2010). Past PMCAMx studies have shown that the base-case OA scheme used in PMCAMx represents reasonably well the average atmospheric chemistry of OA.

\subsection{Black carbon}

More than $70 \%$ of the hourly summertime BC data are predicted within a factor of two from all three sites (Fig. 5). The model, in agreement with the measurements, predicts the largest BC concentrations in the city center and the lowest at the suburban site of SIRTA. The overall mean bias $\left(0.05 \mu \mathrm{g} \mathrm{m}^{-3}\right)$ shows encouraging agreement without any systematic errors. During the winter period, with the exception of SIRTA where only $12 \mathrm{~h}$ data were available, the model performs similarly to the summer period with $68 \%$ of the data predicted within a factor of two (Fig. 5). A slightly higher overprediction is seen in LHVP (mean bias $=0.5 \mu \mathrm{g} \mathrm{m}^{-3}$ ) compared to the summer period (Fig. S1). Both the model and the observations show higher $\mathrm{BC}$ concentrations in GOLF than in the city center due to a strong influence of nearby traffic.
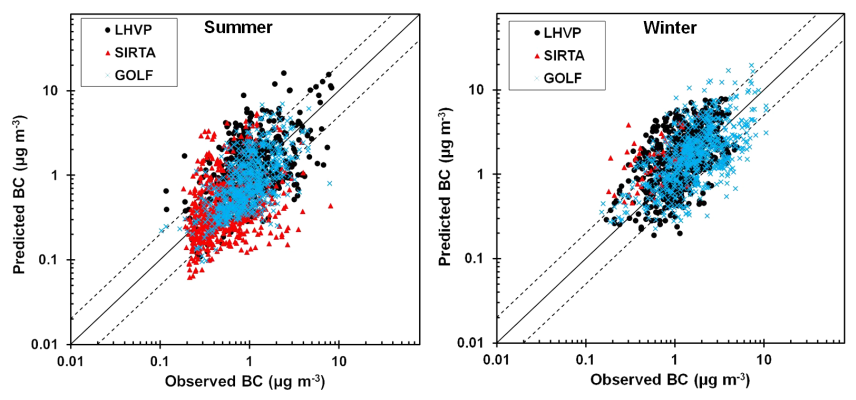

Figure 5. Comparison of predicted vs. observed fine BC $\left(\mu \mathrm{g} \mathrm{m}^{-3}\right)$ from the three measurement stations during the MEGAPOLI summer and winter campaigns. Each point is an hourly average value with the exception of wintertime data at SIRTA where only $12 \mathrm{~h}$ data were available. Also shown are the $1: 1,2: 1$ and $1: 2$ lines.

Figure 6 shows the average diurnal profile of predicted and observed BC concentrations. PMCAMx does a reasonable job in predicting the low concentrations (minima of the curves) of BC during both periods and in both the city center and the suburbs reproducing even the low levels of $\mathrm{BC}$ in SIRTA (down to $0.3 \mu \mathrm{g} \mathrm{m}^{-3}$ in the evening). The small overpredictions in LHVP during summer and in both LHVP and GOLF during winter are mostly during the morning peak and could be related to errors in the traffic emission inventory, errors in the geographical distribution of emissions in the highresolution inventory (Fountoukis et al., 2013) or to an underestimation of the mixing height by the model. Boundary layer height observations were only available in the SIRTA site.

A time series analysis of BC concentrations at SIRTA showed that the model overpredicted the morning peak $\mathrm{BC}$ concentrations by more than a factor of two on 13, 21 and 29 July. On 13 July the model-simulated mixing height is within $10 \%$ of the observed values while on the other 2 days the model underestimated the mixing height (up to $1200 \mathrm{~m}$ for an observed mixing height of about $3000 \mathrm{~m}$ during the day). It is difficult to quantify the extent of the error this model underestimation would induce to $\mathrm{BC}$ concentrations since the mixing height observations are also uncertain. Hodzic et al. (2009) reported a positive bias of 300-1000 $\mathrm{m}$ in the mixing height diagnosed from LIDAR observations (used here), as compared to the one from radiosonde profiles. For an estimated $20 \%$ average underprediction of the mixing height during summer we corrected BC concentrations in Paris city center by the same magnitude. This slightly improved model performance (MB reduced from 0.3 to $-0.1 \mu \mathrm{g} \mathrm{m}^{-3}$ ) showing that the mixing height underestimation could partly explain the BC discrepancy, however this is a rather simplified correction since a large part $(40 \%)$ of the city's BC concentration is transported from outside the city (Skyllakou et al., 2014). Furthermore, the model presents a delay in the timing of the morning rise of the boundary layer during both summer and winter that could also explain part of the BC 

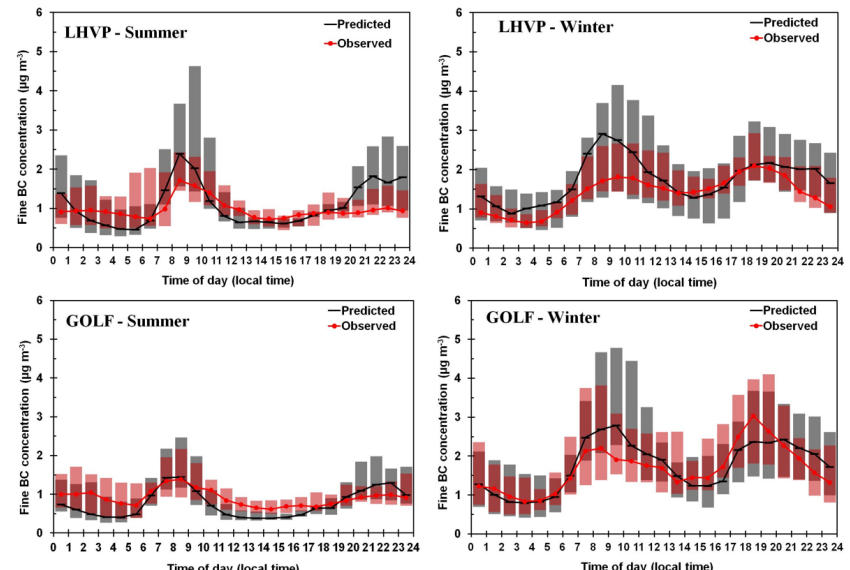

Time of day (local time)

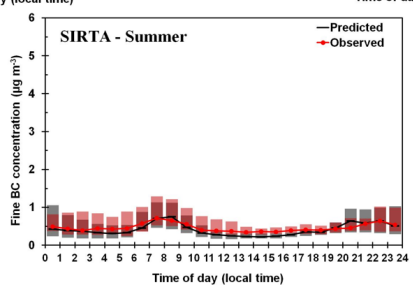

Figure 6. Average diurnal profiles of fine BC concentrations from the three measurement stations during the MEGAPOLI summer and winter campaigns. The shaded vertical bars indicate the 25 th and 75th percentiles (gray color represents the predicted and pink the observed values).

overprediction in the morning (Fig. S7). Overall, the model predicts, in agreement with the measurements, surprisingly low concentrations of $\mathrm{BC}$ for a megacity of 10.5 million inhabitants (Beekmann et al., 2015).

\subsection{Estimation of cooking OA emissions}

Based on the comparison with the factor-analysis AMS data for COA (Sect. 5.2) a sensitivity simulation was run in which emissions of primary OA were increased by a factor of 3 during summer and 1.5 during winter to roughly account for the missing cooking emissions. These emissions were geographically distributed in the Paris greater area following the pattern of the population density. It should be noted that since IVOCs are assumed proportional to the emitted primary OA mass, the addition of COA came with an increase of the IVOC emissions as well. The total OC emissions added were 5.3 tons $\mathrm{d}^{-1}$ for the summer and 5.1 tons $\mathrm{d}^{-1}$ for the winter period, or approximately $80 \mathrm{mg} \mathrm{d}^{-1}$ per capita during each period. A distinct diurnal emission profile was used taking into consideration that COA concentrations were characterized by a prominent diurnal pattern with peak values during meal times (Crippa et al., 2013b). A variation of weekly emissions was also considered with approximately $18.5 \%$ of total weekly COA emitted (per day) on weekend days and $12.5 \%$ on weekdays. Figure S8 shows the temporal profile of the added cooking emissions during the summer period.
The wintertime temporal profile used slightly differs from the summertime one since these are based on the observed diurnal patterns of COA concentrations. As expected, PMCAMx predictions for total POA concentrations are much closer to observations when COA emissions are included in the inventory (Fig. 7, Table 4). The average summertime predicted total POA is increased to $0.7 \mu \mathrm{g} \mathrm{m}^{-3}$ and the fractional bias drops from -0.7 to 0.05 while the number of data predicted within a factor of two increases from 30 to $60 \%$. In the other two sites the addition of COA considerably improves model predictions although a systematic underprediction still exists ( $\mathrm{MB}=-0.2 \mu \mathrm{g} \mathrm{m}^{-3}$ in SIRTA and $-1 \mu \mathrm{g} \mathrm{m}^{-3}$ in GOLF) which could be due to the simplified approach of distributing the COA emissions by population density in the greater area of Paris. During the winter period the addition of COA results in a reduced model bias for total POA concentrations in Paris city center (FBIAS drops from -0.3 to -0.01 ) but also an overprediction $\left(\mathrm{MB}=0.5 \mu \mathrm{g} \mathrm{m}^{-3}\right.$ ) that is mainly from the errors in BBOA discussed in Sect. 5.2. The model performance for OOA remains practically unchanged with the addition of COA during both seasons (Table 4). Figure 8 shows the averaged diurnal profile of COA concentrations predicted and observed during both seasons in LHVP and SIRTA. In SIRTA the model predicts low concentrations $\left(<0.5 \mu \mathrm{g} \mathrm{m}^{-3}\right)$ throughout the day during moth seasons in agreement with observations. In the city center the two peaks observed during meal times are reproduced with reasonable accuracy. Interestingly, this agreement is achieved when $50 \%$ of the daily cooking emissions is emitted during lunch time (12:00-14:00 LT) and only $20 \%$ during dinner time (20:00-22:00 LT), although the nighttime maximum COA concentration is higher than the midday maximum (by a factor of two in summer). This is due to a strong vertical mixing during the summer days. During the winter period the addition of cooking OA emissions in the city center decreases the fractional bias for total POA concentrations in LHVP from -0.3 to -0.01 and in general significantly improves model predictions.

In a sensitivity test, we added cooking OA emissions in the entire domain assuming the same emission rate per person as in Paris. This is clearly a crude zeroth order approximation. Addition of cooking OA emissions to the inventory, leads to an increase of the total OA emissions by as much as a factor of 2-3 in some highly populated areas (Fig. S9). These additional European cooking OA emissions do affect OA levels in Paris. Assuming similar chemical aging parameters as for the transportation OA we estimated that these emissions could increase average $\mathrm{OA}$ in Paris by $0.1-0.2 \mu \mathrm{g} \mathrm{m}^{-3}$ on average; a small but non-negligible contribution.

\section{Conclusions}

PMCAMx, a 3-D chemical transport model, was applied using both regional and urban domains to simulate the forma- 
Table 4. Prediction skill metrics of PMCAMx with the addition of COA against observed hourly data.

\begin{tabular}{lrrrr|rrrr}
\hline & \multicolumn{4}{c}{ Summer } & \multicolumn{4}{c}{ Winter } \\
\cline { 2 - 8 } POA & LHVP & SIRTA & GOLF & Average & LHVP & SIRTA & GOLF & Average \\
\hline Mean predicted $\left(\mu \mathrm{g} \mathrm{m}^{-3}\right)$ & 0.7 & 0.3 & 0.6 & 0.6 & 3 & 1.7 & 2 & 2.3 \\
Mean observed $\left(\mu \mathrm{g} \mathrm{m}^{-3}\right)$ & 0.7 & 0.5 & 1.6 & 1 & 2.7 & 2.4 & 1.3 & 2.2 \\
FERROR & 0.6 & 0.8 & 0.9 & 0.7 & 0.6 & 0.7 & 0.7 & 0.7 \\
FBIAS & 0.05 & -0.5 & -0.8 & -0.5 & -0.01 & -0.5 & 0.3 & -0.1 \\
MAGE $\left(\mu \mathrm{g} \mathrm{m}^{-3}\right)$ & 0.4 & 0.3 & 1 & 0.6 & 2 & 1.5 & 1.3 & 1.6 \\
MB $\left(\mu \mathrm{g} \mathrm{m}^{-3}\right)$ & 0.05 & -0.2 & -1 & -0.4 & 0.5 & -0.8 & 0.8 & 0.1 \\
& & & & & & & & \\
OOA & & & & & & & & \\
Mean predicted $\left(\mu \mathrm{g} \mathrm{m}^{-3}\right)$ & 1.6 & 1.5 & 1.6 & 1.5 & 0.8 & 0.7 & 0.8 & 0.8 \\
Mean observed $\left(\mu \mathrm{g} \mathrm{m}^{-3}\right)$ & 1.7 & 1.2 & 1.5 & 1.4 & 3.2 & 3.3 & 3 & 3.2 \\
FERROR & 0.3 & 0.4 & 0.4 & 0.4 & 1.1 & 1.2 & 1.1 & 1.1 \\
FBIAS & -0.05 & 0.1 & 0.02 & 0.05 & -1.1 & -1.1 & -1 & -1.1 \\
MAGE $\left(\mu \mathrm{g} \mathrm{m}^{-3}\right)$ & 0.5 & 0.5 & 0.5 & 0.5 & 2.3 & 2.6 & 2.1 & 2.3 \\
MB $\left(\mu \mathrm{g} \mathrm{m}^{-3}\right)$ & -0.1 & 0.3 & 0.08 & 0.1 & -2.3 & -2.6 & -2 & -2.3 \\
\hline
\end{tabular}
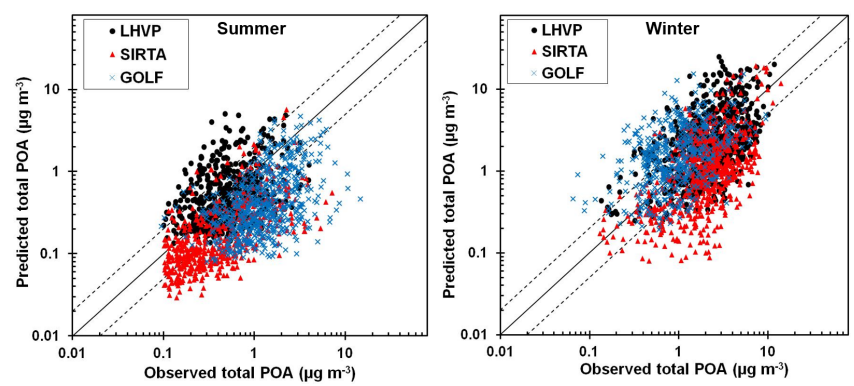

Figure 7. Comparison of predicted vs. observed $\mathrm{PM}_{1}$ total POA $\left(\mu \mathrm{g} \mathrm{m}^{-3}\right)$, including the added COA emissions, from the three measurement stations during the MEGAPOLI summer and winter campaigns. Each point is an hourly average value. Also shown are the $1: 1,2: 1$ and $1: 2$ lines. Observed data represent AMS factoranalysis results.

tion of carbonaceous aerosol during the MEGAPOLI summer and winter campaigns. A high grid resolution over the Paris greater area along with high-resolution emissions $\left(4 \times 4 \mathrm{~km}^{2}\right)$ was used to examine the role of sources and production mechanisms in the organic aerosol and BC concentrations.

PMCAMx predicts BC concentrations reasonably well during both periods and in both the city center and the suburbs (FBIAS $=-0.1$ in summer and 0.1 in winter) reproducing the majority $(70 \%)$ of the hourly data within a factor of two. The largest source of summertime BC concentrations is traffic $(70 \%)$ and of wintertime the residential combustion $(45 \%)$. Almost $60 \%$ of the $\mathrm{BC}$ is predicted to originate from local sources during both summer and winter.

The agreement for the summertime secondary OA concentrations is also encouraging (mean bias $=0.1 \mu \mathrm{g} \mathrm{m}^{-3}$ ) highlighting the ability of the model to reproduce the major
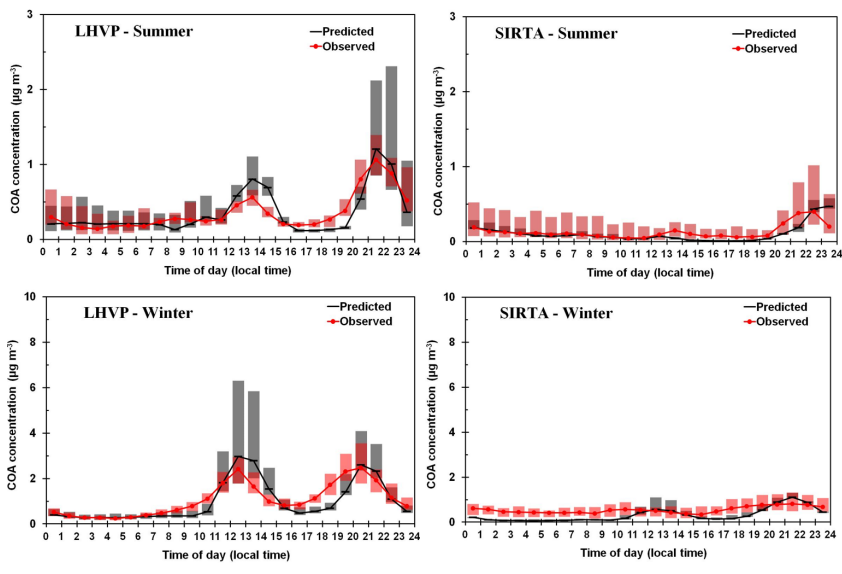

Figure 8. Average diurnal profile of COA concentrations in LHVP and SIRTA during the MEGAPOLI summer and winter campaigns. The shaded vertical bars indicate the 25 th and 75 th percentiles (gray color represents the predicted and pink the observed values)

secondary OA transport and transformation processes during a photochemically intense period. The model predicts that during the summer a large fraction $(54 \%)$ of the OOA concentration in the city center is comprised of SOA from biogenic VOCs followed by SOA from semi-volatile and intermediate-volatility VOCs $(33 \%)$ while a smaller fraction $(13 \%)$ consists of SOA from anthropogenic VOCs.

Wintertime simulations showed a surprisingly large underestimation of OOA in the Paris greater area (mean bias $=-2.3 \mu \mathrm{g} \mathrm{m}^{-3}$ ) that has not been reported in any of the previous applications of the model in either the European or the United States domain. A process forming secondary OA (in a polluted environment with high $\mathrm{NO}_{x}$ concentrations and 
in the absence of light) that is not simulated in the model could partly explain this underprediction.

The model evaluation for primary OA concentrations revealed a major deficiency of the emission inventory, namely the missing primary organic aerosol emissions from cooking activities during both summer and winter. Based on the comparison with the factor-analysis AMS data for cooking OA, more than 5 tons $\mathrm{d}^{-1}$ (or $80 \mathrm{mg} \mathrm{d}^{-1}$ per capita) should be added in the emission inventory with a distinct diurnal profile in which $50 \%$ of the daily cooking emissions are emitted during lunch time (12:00-2:00 p.m.) and 20\% during dinner time (8:00-10:00 p.m.). This addition improved significantly the model performance for both summer and winter. This work strongly supports that much more attention should be paid to the OA emission inventories of megacities and more specifically to the cooking source sector. However, the remarkable diurnal variation of these emissions shows that more research is also needed towards a better understanding of which activities contribute to these emissions (e.g. meat grilling is one known important source of COA; Mohr et al., 2009).

Focusing on ambient primary OA concentrations, the cooking source seems to be an attractive target for pollutionreduction strategies since COA contributes $70 \%$ to total primary OA concentrations during summer. During winter both cooking $(40 \%)$ and biomass burning $(40 \%)$ are the two major contributors. Focusing on reducing BC concentrations, however, the traffic sector deserves the most attention during summer with the addition of residential combustion in winter.

\section{The Supplement related to this article is available online at doi:10.5194/acp-16-3727-2016-supplement.}

Acknowledgements. This work was funded by the EU FP7 project MEGAPOLI (Grant Agreement no.: 212520), the EU FP7 IDEAS ATMOPACS project (grant agreement 267099) and the ARISTEIA ROMANDE project (National Research Excellence Grant).

Edited by: A. Baklanov

\section{References}

Airparif: Ile-de-France gridded emission inventory 2005 (version 2008), http://www.airparif.asso.fr/ (last access: 1 October 2015), 2010.

Allan, J. D., Williams, P. I., Morgan, W. T., Martin, C. L., Flynn, M. J., Lee, J., Nemitz, E., Phillips, G. J., Gallagher, M. W., and Coe, H.: Contributions from transport, solid fuel burning and cooking to primary organic aerosols in two UK cities, Atmos. Chem. Phys., 10, 647-668, doi:10.5194/acp-10-647-2010, 2010.
Atkinson, R. and Arey, J.: Atmospheric degradation of volatile organic compounds, Chem. Rev., 103, 4605-4638, 2003.

Beekmann, M., Prévôt, A. S. H., Drewnick, F., Sciare, J., Pandis, S. N., Denier van der Gon, H. A. C., Crippa, M., Freutel, F., Poulain, L., Ghersi, V., Rodriguez, E., Beirle, S., Zotter, P., von der Weiden-Reinmüller, S.-L., Bressi, M., Fountoukis, C., Petetin, H., Szidat, S., Schneider, J., Rosso, A., El Haddad, I., Megaritis, A., Zhang, Q. J., Michoud, V., Slowik, J. G., Moukhtar, S., Kolmonen, P., Stohl, A., Eckhardt, S., Borbon, A., Gros, V., Marchand, N., Jaffrezo, J. L., Schwarzenboeck, A., Colomb, A., Wiedensohler, A., Borrmann, S., Lawrence, M., Baklanov, A., and Baltensperger, U.: In situ, satellite measurement and model evidence on the dominant regional contribution to fine particulate matter levels in the Paris megacity, Atmos. Chem. Phys., 15, 9577-9591, doi:10.5194/acp-15-9577-2015, 2015.

Bergström, R., Denier van der Gon, H. A. C., Prévôt, A. S. H., Yttri, K. E., and Simpson, D.: Modelling of organic aerosols over Europe (2002-2007) using a volatility basis set (VBS) framework: application of different assumptions regarding the formation of secondary organic aerosol, Atmos. Chem. Phys., 12, 8499-8527, doi:10.5194/acp-12-8499-2012, 2012.

Bougiatioti, A., Stavroulas, I., Kostenidou, E., Zarmpas, P., Theodosi, C., Kouvarakis, G., Canonaco, F., Prévôt, A. S. H., Nenes, A., Pandis, S. N., and Mihalopoulos, N.: Processing of biomassburning aerosol in the eastern Mediterranean during summertime, Atmos. Chem. Phys., 14, 4793-4807, doi:10.5194/acp-144793-2014, 2014.

Canonaco, F., Crippa, M., Slowik, J. G., Baltensperger, U., and Prévôt, A. S. H.: SoFi, an IGOR-based interface for the efficient use of the generalized multilinear engine (ME-2) for the source apportionment: ME-2 application to aerosol mass spectrometer data, Atmos. Meas. Tech., 6, 3649-3661, doi:10.5194/amt6-3649-2013, 2013.

Couvidat, F., Kim, Y., Sartelet, K., Seigneur, C., Marchand, N., and Sciare, J.: Modeling secondary organic aerosol in an urban area: application to Paris, France, Atmos. Chem. Phys., 13, 983-996, doi:10.5194/acp-13-983-2013, 2013.

Crippa, M., DeCarlo, P. F., Slowik, J. G., Mohr, C., Heringa, M. F., Chirico, R., Poulain, L., Freutel, F., Sciare, J., Cozic, J., Di Marco, C. F., Elsasser, M., Nicolas, J. B., Marchand, N., Abidi, E., Wiedensohler, A., Drewnick, F., Schneider, J., Borrmann, S., Nemitz, E., Zimmermann, R., Jaffrezo, J.-L., Prévôt, A. S. H., and Baltensperger, U.: Wintertime aerosol chemical composition and source apportionment of the organic fraction in the metropolitan area of Paris, Atmos. Chem. Phys., 13, 961-981, doi:10.5194/acp-13-961-2013, 2013a.

Crippa, M., Canonaco, F., Slowik, J. G., El Haddad, I., DeCarlo, P. F., Mohr, C., Heringa, M. F., Chirico, R., Marchand, N., Temime-Roussel, B., Abidi, E., Poulain, L., Wiedensohler, A., Baltensperger, U., and Prévôt, A. S. H.: Primary and secondary organic aerosol origin by combined gas-particle phase source apportionment, Atmos. Chem. Phys., 13, 8411-8426, doi:10.5194/acp-13-8411-2013, 2013b.

Crippa, M., El Haddad, I., Slowik, J. G., DeCarlo, P. F., Mohr, C., Heringa, M. F., Chirico, R., Marchand, N., Sciare, J., Baltensperger, U., and Prévôt, A. S. H.: Identification of marine and continental aerosol sources in Paris using high resolution aerosol mass spectrometry, J. Geophys. Res., 118, 1950-1963, doi:10.1002/jgrd.50151, 2013c. 
DeCarlo, P. F., Kimmel, J. R., Trimborn, A., Northway, M. J., Jayne, J. T., Aiken, A. C., Gonin, M., Fuhrer, K., Horvath, T., Docherty, K. S., Worsnop, D. R., and Jimenez, J. L.: Field-deployable, high-resolution, time-of-flight aerosol mass spectrometer, Anal. Chem., 78, 8281-8289, 2006.

Denier van der Gon, H. A. C., Beevers, S., D’Allura, Al., Finardi, S., Honoré, C., Kuenen, J., Perrussel, O., Radice, P., Theloke, J., Uzbasich, M., and Visschedijk, A.: Discrepancies Between TopDown and Bottom-Up Emission Inventories of Megacities: The Causes and Relevance for Modeling Concentrations and Exposure, in: NATO Science for Peace and Security Series C: Environmental Security, edited by: Steyn, D. G. and Castelli, S. T., Vol. 4, Springer, the Netherlands, ISBN 978-94-007-1358-1, p. 772,2011

Denier van der Gon, H. A. C., Bergström, R., Fountoukis, C., Johansson, C., Pandis, S. N., Simpson, D., and Visschedijk, A. J. H.: Particulate emissions from residential wood combustion in Europe - revised estimates and an evaluation, Atmos. Chem. Phys., 15, 6503-6519, doi:10.5194/acp-15-6503-2015, 2015.

Donahue, N. M., Robinson, A. L., Stanier, C. O., and Pandis, S. N.: Coupled partitioning, dilution, and chemical aging of semivolatile organics, Environ. Sci. Technol., 40, 2635-2643, 2006

Donahue, N. M., Robinson, A. L., and Pandis, S. N.: Atmospheric organic particulate matter: From smoke to secondary organic aerosol, Atmos Environ., 43, 94-106, 2009.

Drewnick, F., Hings, S. S., DeCarlo, P., Jayne, J. T., Gonin, M., Fuhrer, K., Weimer, S., Jimenez, J. L., Demerjian, K. L., Borrmann, S., and Worsnop, D. R.: A new time-of-flight aerosol mass spectrometer (TOF-AMS) - Instrument description and first field deployment, Aerosol Sci. Tech., 39, 637-658, 2005.

ENVIRON: User's Guide to the Comprehensive Air Quality Model with Extensions (CAMx), Version 4.02, Report, ENVIRON Int. Corp., Novato, California, available at: http://www.camx.com (last access: 1 December 2013), 2003.

Favez, O., Cachier, H., Sciare, J., and Le Moullec, Y.: Characterization and contribution to $\mathrm{PM}_{2.5}$ of semi-volatile aerosols in Paris (France), Atmos. Environ., 41, 7969-7976, 2007.

Fountoukis, C., Racherla, P. N., Denier van der Gon, H. A. C., Polymeneas, P., Haralabidis, P. E., Wiedensohler, A., Pilinis, C., and Pandis, S. N: Evaluation of a three-dimensional chemical transport model (PMCAMx) in the European domain during the EUCAARI May 2008 campaign, Chem. Phys., 11, 14183-14220, 2011.

Fountoukis, C., Koraj, D., Denier van der Gon, H. A. C., Charalampidis, P. E., Pilinis, C., and Pandis, S. N.: Impact of grid resolution on the predicted fine PM by a regional 3-D chemical transport model, Atmos. Environ., 68, 24-32, 2013.

Fountoukis, C., Butler, T., Lawrence, M. G., Denier van der Gon, H. A. C., Visschedijk, A. J. H., Charalampidis, P., Pilinis, C., and Pandis, S. N.: Impacts of controlling biomass burning emissions on wintertime carbonaceous aerosol in Europe, Atmos. Environ. $87,175-182,2014 a$.

Fountoukis, C., Megaritis, A. G., Skyllakou, K., Charalampidis, P. E., Pilinis, C., Denier van der Gon, H. A. C., Crippa, M., Canonaco, F., Mohr, C., Prévôt, A. S. H., Allan, J. D., Poulain, L., Petäjä, T., Tiitta, P., Carbone, S., Kiendler-Scharr, A., Nemitz, E., O’Dowd, C., Swietlicki, E., and Pandis, S. N.: Organic aerosol concentration and composition over Europe: insights from com- parison of regional model predictions with aerosol mass spectrometer factor analysis, Atmos. Chem. Phys., 14, 9061-9076, doi:10.5194/acp-14-9061-2014, 2014b.

Freney, E. J., Sellegri, K., Canonaco, F., Colomb, A., Borbon, A., Michoud, V., Doussin, J.-F., Crumeyrolle, S., Amarouche, N., Pichon, J.-M., Bourianne, T., Gomes, L., Prevot, A. S. H., Beekmann, M., and Schwarzenböeck, A.: Characterizing the impact of urban emissions on regional aerosol particles: airborne measurements during the MEGAPOLI experiment, Atmos. Chem. Phys., 14, 1397-1412, doi:10.5194/acp-14-1397-2014, 2014.

Freutel, F., Schneider, J., Drewnick, F., von der Weiden-Reinmüller, S.-L., Crippa, M., Prévôt, A. S. H., Baltensperger, U., Poulain, L., Wiedensohler, A., Sciare, J., Sarda-Estève, R., Burkhart, J. F., Eckhardt, S., Stohl, A., Gros, V., Colomb, A., Michoud, V., Doussin, J. F., Borbon, A., Haeffelin, M., Morille, Y., Beekmann, M., and Borrmann, S.: Aerosol particle measurements at three stationary sites in the megacity of Paris during summer 2009: meteorology and air mass origin dominate aerosol particle composition and size distribution, Atmos. Chem. Phys., 13, 933-959, doi:10.5194/acp-13-933-2013, 2013.

Guenther, A., Karl, T., Harley, P., Wiedinmyer, C., Palmer, P. I., and Geron, C.: Estimates of global terrestrial isoprene emissions using MEGAN (Model of Emissions of Gases and Aerosols from Nature), Atmos. Chem. Phys., 6, 3181-3210, doi:10.5194/acp-63181-2006, 2006.

Haeffelin, M., Barthès, L., Bock, O., Boitel, C., Bony, S., Bouniol, D., Chepfer, H., Chiriaco, M., Cuesta, J., Delanoë, J., Drobinski, P., Dufresne, J.-L., Flamant, C., Grall, M., Hodzic, A., Hourdin, F., Lapouge, F., Lemaître, Y., Mathieu, A., Morille, Y., Naud, C., Noël, V., O’Hirok, W., Pelon, J., Pietras, C., Protat, A., Romand, B., Scialom, G., and Vautard, R.: SIRTA, a ground-based atmospheric observatory for cloud and aerosol research, Ann. Geophys., 23, 253-275, doi:10.5194/angeo-23-253-2005, 2005.

Hallquist, M., Wenger, J. C., Baltensperger, U., Rudich, Y., Simpson, D., Claeys, M., Dommen, J., Donahue, N. M., George, C., Goldstein, A. H., Hamilton, J. F., Herrmann, H., Hoffmann, T., Iinuma, Y., Jang, M., Jenkin, M. E., Jimenez, J. L., Kiendler-Scharr, A., Maenhaut, W., McFiggans, G., Mentel, Th. F., Monod, A., Prévôt, A. S. H., Seinfeld, J. H., Surratt, J. D., Szmigielski, R., and Wildt, J.: The formation, properties and impact of secondary organic aerosol: current and emerging issues, Atmos. Chem. Phys., 9, 5155-5236, doi:10.5194/acp-9-51552009, 2009.

Hersey, S. P., Craven, J. S., Schilling, K. A., Metcalf, A. R., Sorooshian, A., Chan, M. N., Flagan, R. C., and Seinfeld, J. H.: The Pasadena Aerosol Characterization Observatory (PACO): chemical and physical analysis of the Western Los Angeles basin aerosol, Atmos. Chem. Phys., 11, 7417-7443, doi:10.5194/acp11-7417-2011, 2011.

Hodzic, A., Jimenez, J. L., Madronich, S., Aiken, A. C., Bessagnet, B., Curci, G., Fast, J., Lamarque, J.-F., Onasch, T. B., Roux, G., Schauer, J. J., Stone, E. A., and Ulbrich, I. M.: Modeling organic aerosols during MILAGRO: importance of biogenic secondary organic aerosols, Atmos. Chem. Phys., 9, 6949-6981, doi:10.5194/acp-9-6949-2009, 2009.

Knote, C., Hodzic, A., Jimenez, J. L., Volkamer, R., Orlando, J. J., Baidar, S., Brioude, J., Fast, J., Gentner, D. R., Goldstein, A. H., Hayes, P. L., Knighton, W. B., Oetjen, H., Setyan, A., Stark, H., Thalman, R., Tyndall, G., Washenfelder, R., Waxman, E., and 
Zhang, Q.: Simulation of semi-explicit mechanisms of SOA formation from glyoxal in aerosol in a 3-D model, Atmos. Chem. Phys., 14, 6213-6239, doi:10.5194/acp-14-6213-2014, 2014.

Kostenidou, E., Kaltsonoudis, C., Tsiflikiotou, M., Louvaris, E., Russell, L. M., and Pandis, S. N.: Burning of olive tree branches: a major organic aerosol source in the Mediterranean, Atmos. Chem. Phys., 13, 8797-8811, doi:10.5194/acp-13-8797-2013, 2013.

Kuenen, J., Denier van der Gon, H., Visschedijk, A., van der Brugh, H., Finardi, S., Radice, P., d'Allura, A., Beevers, S., Theloke, J., Uzbasich, M., Honoré, C., and Perrussel, O.: MEGAPOLI Scientific Report 10-17: A Base Year (2005) MEGAPOLI European Gridded Emission Inventory, MEGAPOLI Deliverable D1.6., 2010.

Lane, T. E., Donahue, N. M., and Pandis, S. N.: Simulating secondary organic aerosol formation using the volatility basis-set approach in a chemical transport model, Atmos. Environ., 42, 7439-7451, 2008.

Mohr, C., Huffman, J. A., Cubison, M. J., Aiken A. C., Docherty K. S., Kimmel J. R., Ulbrich I. M., Hannigan M., and Jimenez J. L.: Characterization of primary organic aerosol emissions from meat cooking, trash burning, and motor vehicles with High-Resolution Aerosol Mass Spectrometry and comparison with ambient and chamber Observations, Environ. Sci. Technol., 43, 2443-2449, 2009.

Molina, L. T., Madronich, S., Gaffney, J. S., Apel, E., de Foy, B., Fast, J., Ferrare, R., Herndon, S., Jimenez, J. L., Lamb, B., Osornio-Vargas, A. R., Russell, P., Schauer, J. J., Stevens, P. S., Volkamer, R., and Zavala, M.: An overview of the MILAGRO 2006 Campaign: Mexico City emissions and their transport and transformation, Atmos. Chem. Phys., 10, 8697-8760, doi:10.5194/acp-10-8697-2010, 2010.

Murphy, B. N., Donahue, N. M., Fountoukis, C., and Pandis, S. N.: Simulating the oxygen content of ambient organic aerosol with the 2D volatility basis set, Atmos. Chem. Phys., 11, 7859-7873, doi:10.5194/acp-11-7859-2011, 2011.

Murphy, B. N., Donahue, N. M., Fountoukis, C., Dall'Osto, M., O'Dowd, C., Kiendler-Scharr, A., and Pandis, S. N.: Functionalization and fragmentation during ambient organic aerosol aging: application of the 2-D volatility basis set to field studies, Atmos. Chem. Phys., 12, 10797-10816, doi:10.5194/acp-1210797-2012, 2012.

O’Dowd, C. D., Langmann, B., Varghese, S., Scannell, C., Ceburnis, D., and Facchini, M. C.: A combined organic-inorganic sea-spray source function, Geophys. Res. Lett., 35, L01801, doi:10.1029/2007GL030331, 2008.

Paatero, P.: The multilinear engine - A table-driven, least squares program for solving multilinear problems, including the n-way parallel factor analysis model, J. Comput. Graph. Stat., 8, 854888, 1999.

Pouliot, G., Pierce, T., Denier van der Gon, H., Schaap, M., and Nopmongcol, U.: Comparing Emissions Inventories and ModelReady Emissions Datasets between Europe and North America for the AQMEII Project, Atmos. Environ., 53, 4-14, 2012.

Robinson, A. L., Donahue, N. M., Shrivastava, M. K., Weitkamp, E. A., Sage, A. M., Grieshop, A. P., Lane, T. E., Pierce, J. R., and Pandis, S. N.: Rethinking organic aerosols: Semi-volatile emissions and photochemical aging, Science, 315, 1259-1262, 2007.
Sciare, J., d'Argouges, O., Zhang, Q. J., Sarda-Estève, R., Gaimoz, C., Gros, V., Beekmann, M., and Sanchez, O.: Comparison between simulated and observed chemical composition of fine aerosols in Paris (France) during springtime: contribution of regional versus continental emissions, Atmos. Chem. Phys., 10, 11987-12004, doi:10.5194/acp-10-11987-2010, 2010.

Seinfeld, J. H. and Pandis, S. N.: Atmospheric chemistry and physics: From air pollution to climate change, 2nd Edn., John Wiley and Sons, Hoboken, NJ, 2006.

Shrivastava, M. K., Lane, T. E., Donahue, N. M., Pandis, S. N., and Robinson, A. L.: Effects of gas-particle partitioning and aging of primary emissions on urban and regional organic aerosol concentrations, J. Geophys. Res., 113, D18301, doi:10.1029/2007JD009735, 2008.

Skamarock, W. C., Klemp, J. B., Dudhia, J., Gill, D. O., Barker, D. M., Wang, W., and Powers, J. G.: A Description of the Advanced Research WRF Version 3. NCAR Technical Note, available at: www2.mmm.ucar.edu/wrf/users/docs/user_guide_ V3/ARWUsersGuideV3.pdf (last access: 1 March 2016), 2008.

Skyllakou, K., Murphy, B. N., Megaritis, A. G., Fountoukis, C., and Pandis, S. N.: Contributions of local and regional sources to fine PM in the megacity of Paris, Atmos. Chem. Phys., 14, 2343 2352, doi:10.5194/acp-14-2343-2014, 2014.

Sofiev, M., Vankevich, R., Lotjonen, M., Prank, M., Petukhov, V., Ermakova, T., Koskinen, J., and Kukkonen, J.: An operational system for the assimilation of the satellite information on wildland fires for the needs of air quality modelling and forecasting, Atmos. Chem. Phys., 9, 6833-6847, doi:10.5194/acp-9-68332009, 2009.

Sun, J., Zhang, Q., Canagaratna, M. R., Zhang, Y., Ng, N. L., Sun, Y., Jayne, J. T., Zhang, X., Zhang, X., and Worsnop, D. R.: Highly time- and size-resolved characterization of submicron aerosol particles in Beijing using an Aerodyne Aerosol Mass Spectrometer, Atmos. Environ., 44, 131-140, doi:10.1016/j.atmosenv.2009.03.020, 2010.

Sun, Y.-L., Zhang, Q., Schwab, J. J., Demerjian, K. L., Chen, W.N., Bae, M.-S., Hung, H.-M., Hogrefe, O., Frank, B., Rattigan, O. V., and Lin, Y.-C.: Characterization of the sources and processes of organic and inorganic aerosols in New York city with a high-resolution time-of-flight aerosol mass apectrometer, Atmos. Chem. Phys., 11, 1581-1602, doi:10.5194/acp-11-15812011, 2011.

Tsimpidi, A. P., Karydis, V. A., Zavala, M., Lei, W., Molina, L., Ulbrich, I. M., Jimenez, J. L., and Pandis, S. N.: Evaluation of the volatility basis-set approach for the simulation of organic aerosol formation in the Mexico City metropolitan area, Atmos. Chem. Phys., 10, 525-546, doi:10.5194/acp-10-525-2010, 2010.

Ulbrich, I. M., Canagaratna, M. R., Zhang, Q., Worsnop, D. R., and Jimenez, J. L.: Interpretation of organic components from Positive Matrix Factorization of aerosol mass spectrometric data, Atmos. Chem. Phys., 9, 2891-2918, doi:10.5194/acp-9-2891-2009, 2009.

Visschedijk, A. J. H., Zandveld, P., and Denier van der Gon, H. A. C.: TNO Report 2007 A-R0233/B: A high resolution gridded European emission database for the EU integrated project GEMS, the Netherlands, Organization for Applied Scientific Research, 2007.

Xing, J.-H., Takahashi, K., Yabushita, A., Kinugawa, T., Nakayama, T., Matsumi, Y., Tonokura, K., Takami, A., Imamura, T., Sato, 
K., Kawasaki, M., Hikida, T., and Shimono, A.: Characterization of Aerosol Particles in the Tokyo Metropolitan Area using Two Different Particle Mass Spectrometers, Aerosol Sci. Tech., 45, 315-326, 2011.

Zhang, Q., Jimenez, J. L., Canagaratna, M. R., Allan, J. D., Coe, H., Ulbrich, I., Alfarra, M. R., Takami, A., Middlebrook, A. M., Sun, Y. L., Dzepina, K., Dunlea, E., Docherty, K., De-Carlo, P., Salcedo, D., Onasch, T. B., Jayne, J. T., Miyoshi, T., Shimono, A., Hatakeyama, N., Takegawa, N., Kondo, Y., Schneider, J., Drewnick, F., Weimer, S., Demerjian, K. L., Williams, P. I., Bower, K. N., Bahreini, R., Cottrell, L., Griffin, R. J., Rautianen, J., and Worsnop, D. R.: Ubiquity and dominance of oxygenated species in organic aerosols in anthropogenicallyinfluenced Northern Hemisphere midlatitudes, Geophys. Res. Lett., 34, L13801, doi:10.1029/2007GL029979, 2007.
Zhang, Q. J., Beekmann, M., Drewnick, F., Freutel, F., Schneider, J., Crippa, M., Prevot, A. S. H., Baltensperger, U., Poulain, L., Wiedensohler, A., Sciare, J., Gros, V., Borbon, A., Colomb, A., Michoud, V., Doussin, J.-F., Denier van der Gon, H. A. C., Haeffelin, M., Dupont, J.-C., Siour, G., Petetin, H., Bessagnet, B., Pandis, S. N., Hodzic, A., Sanchez, O., Honoré, C., and Perrussel, O.: Formation of organic aerosol in the Paris region during the MEGAPOLI summer campaign: evaluation of the volatilitybasis-set approach within the CHIMERE model, Atmos. Chem. Phys., 13, 5767-5790, doi:10.5194/acp-13-5767-2013, 2013. 